\title{
The Trumpeter Swan
}

\section{By MARGARET BELCHER, REGINA}

One of the things that attracts "birders" to the Cypress Hills is the expectation of seeing a pair of the world's largest swans, the Trumpeters. Only about 1,300 of these rare native swans exist today in North America. They are to be found in small flocks or as individual pairs in Alaska, British Columbia, Alberta, and in the states south of the border. Red Rock Lakes Migratory Waterfowl Refuge in Montana is the home of the American flock of Trumpeters, which fluctuates in size but approximates 600 birds. The birds have a usual range of about 100 miles from the refuge-notably in Yellowstone and Grand Teton National Parks and adjacent National Forests. -but banding returns have proved that there is some interchange of birds between the Canadian and American flocks. The Canadian flock is "at home" about 850 miles north of Red Rock Lakes. In recent years, another breeding flock has been discovered along the Copper River in Alaska (Auk, 1957, 74:92). The only flock left in British Columbia seems to be the one at Lonesome Lake, 300 miles northwest of Vancouver, pictured in the Leader-Post of April 1, 1957.

I have seen Trumpeter Swans only once-a pair in the Wildfowl Trust's sanctuary at Slimbridge, Gloucestershire. These swans were placed in the Trust's care by the Queen to whom they were presented by the Government of Canada and the Government of British Columbia during the Royal Tour in 1952. It seemed strange to see the first pair of Trumpeters so far away from home, when a pair have nested several years in Saskatchewan ir West Block of the Cypress Hill

In 1953 the first Museum ne: record for the Trumpeter in Sas chewan was established (Blue 1953, 11:4:26-27). However, resic of the area had noticed the birc previous years at Bottley's where they nest, and at Adams' and Harris' Lake to which move their young (see item by Percy Drury of Swift Current ir Blue Jay, 1954, 12:2:11).

According to Taverner, the $\mathrm{T}$ peter was at one time a regular $n$ throughout the prairies and $\mathrm{Br}$ Columbia. Perhaps its disappear is accounted for largely by the that it was easily shot. Although one of America's endangered spe the Trumpeter is still being sub ed to hunting pressure. This shown by a fluoroscopic study o birds carried out in 1956 in the Rcck Lakes Refuge. During the mer moult, flightless swans caught by refuge personnel usin thrust boats in a part of the $r$ where no broods would be distu Thirteen out of 100 swans ca lead pellets in their tissue. de the fact that the Trumpeter is o fully protected list. This is prol due to the Trumpeter's being taken for the Snow Goose, a protected species. In any case, proof of hunting pressure emph again the need for untiring effo ensuring the protection, through cation and legislation, of rare like the Trumpeter Swan Whooping Crane.

\section{B I R D}

EVIDENCE OF STRATEGY IN THE HUNTING OF THE SNOWY OWL: One morning while going out to do chores, I noticed a Snowy Owl perched on the combine. As there was a flock of partridge in the trees nearby, I imagined he had tried to catch one and failed, so was waiting for another chance. As I was going into the barn, a few pigeons flew out,

\section{NOTES}

and the owl immediately gave but of course the pigeons had difficulty keeping out of his After a few circles around the the owl gave up and glided to a phone pole, 30 rods east of the aries, and soon the pigeons $s$ down on the east slope of a gr roof, in full view of the owl.

About 20 minutes later 
king toward the house, I saw the leave the pole and fly leisurely northeasterly direction, looking much as if he were leaving, I had already forgotten about when suddenly he flew from bed the house and past me, making ee-line for the granary on which pigeons were sitting. As he was on the northwest side, they did see him until he was among them. dently, as soon as he was out of ht of the pigeons, he made a right ut turn and attempted to surse them. He certainly did surprise $m$, but despite his strategy, he ssed and had to go hungry that rning. This shows that while the 1 was sitting on the pole, he was $\mathrm{ng}$ a bit of thinking, and this is of that our hunting birds as well our hunting animals are capable resorting to cunning when they to catch their prey otherwise.

-S. O. JORDHEIM, White Bear, Sask.

\section{MOUNTAIN CHICKADEE AT} SKINE, ALBERTA - Lloy d M. hr tells of the regular visits this st winter of the Mountain (Gam's) Chickadee-his first record. A puntain resident, the Mountain ickadee is rare in east central Alrta.

FERRUARY RECORD OF GOLN-CROWNED KINGLET NEAR GINA - Two Golden-crowned nglets were observed Feb. 7, 1957, the deciduous trees of the Wasna Creek valley 10 miles northwest Regina. G. F. Ledingham, M. lcher.

DAR WAXWINGS IN MARCHhe Cedar Waxwing is generally nsidered to be the summer waxng. and the Bohemian, the winter axwins. However, a close look is ways indicated, as in recent years hall flocks of Cedar Waxwings have en noted as remaining in Saskatewan until early January. Simiobservations have been made in aniloba and northwestern Ontario. On March 28, 1957, Dr. Stuart ousten noted a flock of fifteen edar Waxwings in the C.P.R. ounds at Yorkton. They presumbly wintered in Saskatchewan, and puld hardly be considered early pring migrants, since the Cedar axwing is ordinarily about the last ird to arrive in the spring. The earl- iest record at Yorkton is May 26, and the average, June 1.

AN ATTACK ON MAN BY A WHOOPING CRANE - Following Fred Lehrman's article on the Aggressive Behaviour of a Whooping Crane Blue Jay, 195', 15:14-15), it is interesting to have James L. Parker of Gilbert Plains, Manitoba recall a record of an attack on man by a Whooping Crane in Grant's and Macoun's accounts of the Sanford Fleming expedition of 1872. Grant describes the incident in Ocizan to Ocean as follows: "On our way to dinner. two large white cranes rose swan-like from a wet marsh near the road. Frank (sixteen year old son of Sir Sanford Fleming) with his gun and Willie (half-breed of same age in charge of the horses) vith a stone made after them. The larger of the two flew high, but Willie's stone brought down the other. As he was seizing it, the big one, evidently the mother, attacked him, but, seeing the gun coming, flew up in time to save herself. The young one was a beautiful bird, the extended wings measuring over six feet from tip to tip. As soon as Willie had killed his game. he rode off in triumph with it slung across his shoulders. In twenty minutes after his arrival at camp, he and his mates had plucked. cooked and disposed of it, all uniting in pronouncing the meat delicate and "first class'."

Macoun also tells of the incident in his Autobicgraphy and says, "the flesh tasted very good, but was a dark colour." The date was August 12,1872 , and the place, according to Grant's map, on the Carlton trail just northwest of the Touchwood hills. Macoun says it was "out on the prairie south of Quill Lake."

If the crane killed was a juvenile it is interesting that it was so well developed on that date. It is hardly probable, however, that a juvenile would be described as white.

\section{BRONZED GRACKLE NESTING} IN BIRD HOUSE - Utilization of bird houses for nesting by species which do not ordinarily nest in holes is uncommon as is indicated by the list compiled by Kalmbach and McAtee (1942. Home for Birds, U.S. Dept. Interior, Cons. Bull. 14:2). Todd (1947. Birds of southern Saskatchewan. Annals Carnegie Mus., Vol. 30.417) reported Bronzed 
Grackles (Quiscalus quiscula) using "sheltered boxes" at Davidson, Saskatchewan, but he gave no details of the box type. Bronzed Grackles have nested in a duck nest barrel at Regina, Saskatchewan, for the past several years, according to Fred W. Lahrman (see photo). This nest barrel has an opening 5 inches in diameter and is fastened about 14 feet above the ground to a pole whichstands some 25 yards back from the edge of Wascana Creek. The barrel was originally set up by Fred G. Bard on his sanctuary to attract Gold e n - e y e ducks (Glaucionetta clangula). Young Grackles fledged from a nest in this barrel about July 4, 1956. Nesting was also successful in 1955 as well as in several previous years. Other Grackles have frequently nested in the usual manner in a small grove of trees which reach to within 10 feet of the nest box. A report of the possible nesting of the Red - winged Blackbird
(Agelaius phoeniceus) in a bi house at Last Mountain Lake, Sa katchewan, has been published in $\mathrm{t}$ Auk (Nero, 1956, 73:284).-R. Nero, Saskatchewan Museum of $\mathrm{N}$ ural History, Regina.

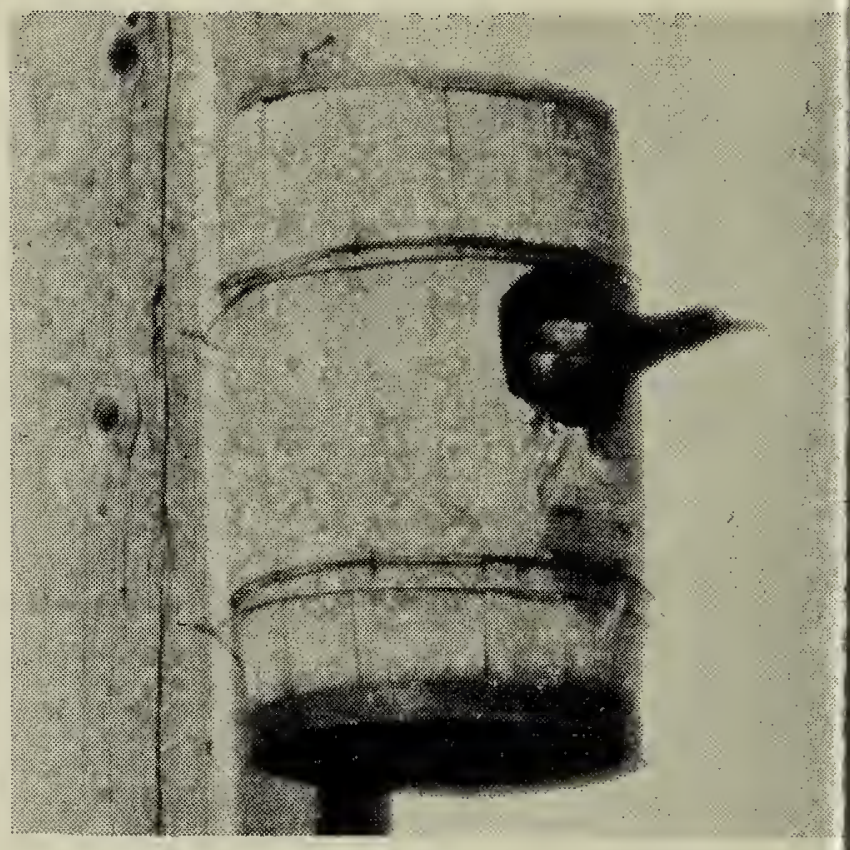

Photo by F.W. Lahri Bronzed Grackle nesting in duck nest ba

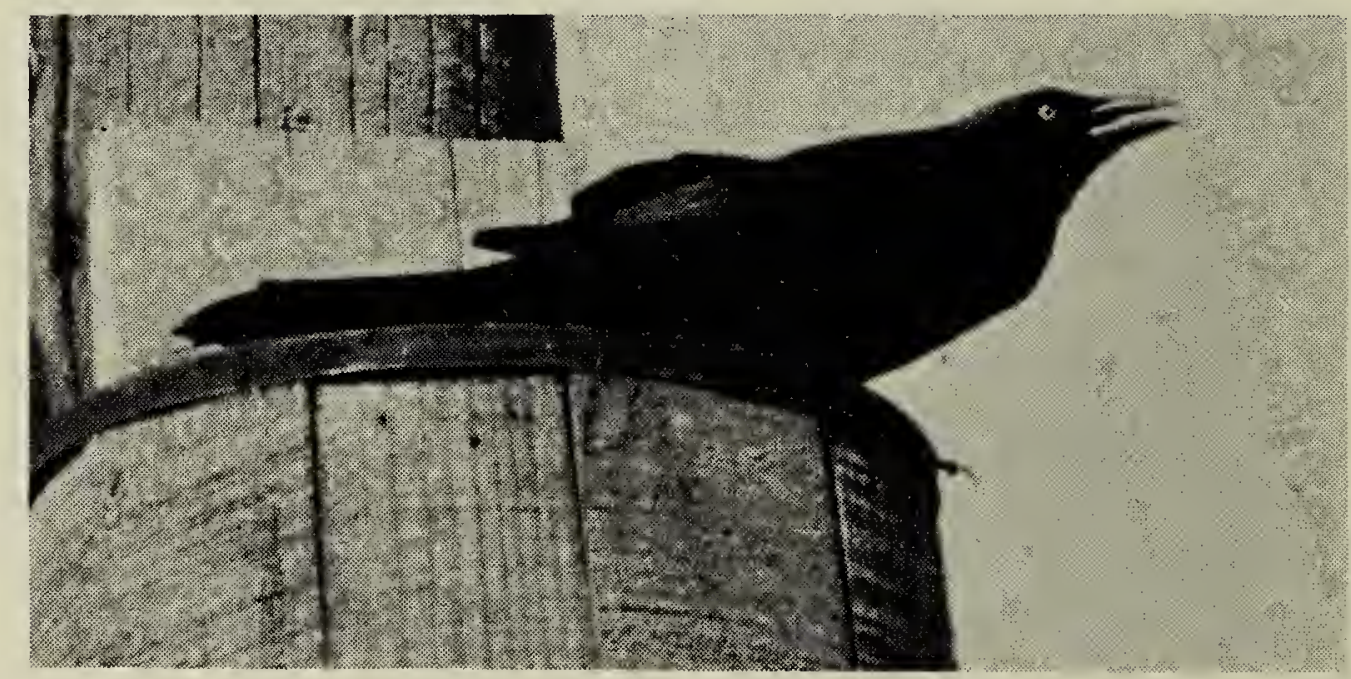

Photo F. W. L Mourning Dove Information Wanted

A year ago the Blue Jay published a request from the U.S. Fish and Wildlife Service asking for assistance in banding Mourning Doves. Fred Bard, Director of the Saskatchewan Museum of Natural History, has received a request again this year for co-operation in the project, from Harold S. Peters, Research Biologist of the U.S. Fish and Wildlife Service, who writes: "We would appreciate having your active assistance in this programme and hope you may induce other persons to band dove nestlings during this summer." For further particulars, see the Blue Jay $(1956,14: 49)$.

In the southern part of its range the Mourning Dove is considered a game bird. In fact, it is the most im- portant of all migratory game bi being harvested in greater numb than all species of waterfowl cc bined. Since Mourning Doves migratory, their hunting is regule by the Federal Government, and U.S. Fish and Wildlife Service therefore interested in any infor tion relevant to the management the bird.

A five year project of dove $n$ ling banding was inaugurated 1956. It met with a fine respc ie from game department personnel interested members of the gen $a$ public, North Dakota leading nation in number of nestlings ban :0 $(3,634)$. The intensified dove $n t$ ling programme is being contin :d in 1957. 